\title{
The Cultural Negotiation of the Minangkabau Elite in Post-New Orders Indonesia: Indonesian and Minangkabaunesse
}

\author{
Y Andoni ${ }^{1}$, D Eros ${ }^{2}$ \\ \{1yudhiandoni12@yahoo.com, ${ }^{2}$ donnyeros@yahoo.com $\}$ \\ ${ }^{1,2}$ Universitas Andalas, Padang, Indonesia
}

\begin{abstract}
Years after the collapse of New Order regime in West Sumatera were important periods for amongst Minangkabau elites build their "cultural projects". This paper elaborates the process of cultural invention among Minangkabau elites during the intensive socio-cultural development. During the Reform Era, the Minangkabau cultural elites managed to organize many effort to place Minangkabau adat (tradition) as the main cultural identity of West Sumatera population, although other ethnic groups such as Java, Sunda, Batak, Nias, Tionghoa and Mentawai stay living peacefully in the province. These elites of Minangkabau tradition set negotiation with the local government to release various local policies concerning the rebuilding the Nagari as the centre for Minangkabau ethnic group and conducting various Minangkabau cultural event. The cultural negotiation received supports from the local government at the level of province, regency and cities of West Sumatera.
\end{abstract}

Keywords: collapse, cultural, invention, negotiation, conflicts

\section{INTRODUCTION}

The fallen down of New Order became the gate of great changes within Indonesian society[1]-[3]. The changes were like a long hold flood, it flows in and destroys all obstacles, structurally and culturally. In particular, the collapsed of Suharto regime, the 1999 Presidential \& Parliamentary election, and the rose of new national leaders, created a process of democratization which brought in significant changes at the grass root[4], including in the West Sumatera. This turning point triggered, as if, the anti-climax in this region which after the PRRI (Minangkabau rebel movement against the central government of Indonesian Republic) in 1958 had been considered as the "children of New Order".

The structural transformation was coined in the UU No. 22 tahun 1999 tentang Pemerintahan Daerah (the law on decentralization of power) which was later implemented in the Local Government law Peraturan Daerah (Perda) No. 9 tahun 2000. This Perda changed the smallest unit of government from Desa (county) which was officially coined to UU No. 5 Tahun 1979 into the Nagari government system. Although the Nagari government system is admited and considered similar to Desa, yet it is culturally different and problematic. In the last 20 years (1999-2019), Pemda including the governor, city major and regent was given strategic position in the West Sumatera society, particularly the Minangkabau. The cultural shift was called "Kembali ke Nagari" which reform the government system under the cultural leaders and "Kembali ke Surau" which gave back the education to the Ulama's (figures in 
Islamic authority), while the Kaum Adat (figures of tradition) demanded a position in between these two strategic institution, Pemda and Ulama.

The main issue addressed by this paper is the inconsistencies in the role and movement of Kaum Adat (Figures of Tradition) in the socio-cultural shift in West Sumatera within the last two decades. This paper explores the various efforts or activities of Kaum Adat in taking parts at the revitalization of Minangkabau adat (traditions) values and positions during the periods. Thus, the paper can elaborate the process of cultural inventions, a theory about the origins and evolution of culture[5], led by the elites of Minangkabau traditions in the period of sociocultural changes.

\section{RESEARCH METHOD}

This research uses the critical historical writing method. The research step starts with collecting data from various libraries in West Sumatra. The library had provided a variety of primary and secondary sources in the form of newspaper articles, books, research reports, and local government policies. The third step of the research method is clarification, validation, and classification of datas which lead to the facts of topic. The facts are understood to make a picture of reality that then is written in the form of historiography.

\section{RESULT AND DISCUSSION}

The unsettled conflict between the tradition and religion have became the result of history construction [6] which in the contemporary period involve more players such as the central and local government. The process of history construction had given born to socio-religious a movement which was started by the Wahabi Movement. This movement was a radical effort to annihilate the gap between religions demands and reality of social life and interactions [7]. However, the Wahabi Movement was essentially failed to change the structure of social, cultural and political structure in Minangkabau communityn[8] [9]. This movement was then known as Paderi Movement, particularly through the movement of Kaum Muda (Youth Representative) in the 1920s. Although, the contestation initially involved Kaum Adat (tradition) and Kaum Agama (religion), it formed new conflicts within Minangkabau society throughout the Dutch Colonial, Indonesian Revolution and New Order periodes which particularly address the issue of identities [10].

In the Dutch colonial period, Minangkabau identity was one that separates them from Islam as other identities[11]. The separation of identities was made to ease the colonial government to control and order (rust en order) the Minangkabau as the local. This developed into national identity when the Minangkabau becoming the part of Indonesia. During the period of New Order, the Minangkabau identity was melted down as one of national cultures. The Minangkabau identity was manifested from the values of Indonesia as a nation. This identity was then corrected during the Reform movement in 1998 and created a contrast gap between the kaum adat, kaum Islam and pemda (local government) in the UU Nomor 22 tahun 1999 (law) which produced a applicable discourse of Adat Basandi Syarak, Syarak Basandi Kitabullah or $A B S S B K$ (Tradition should stand on religion, religion is stand on Islam).

The identity of $A B S S B K$ which is now became a pull-back between Kaum Adat, Kaum Agama and the Government was not the product of contemporary culture of Minangkabau society. Along with the empowerment of civil society as a new power at the post New Order period, $A B S S B K$ which started as symbol of harmonic relation between the tradition and Islam evolved into a standard and direction of West Sumatera policy making. Moreover, the Kaum 
Agama made it as the purpose in their dakwah (teaching), while Kaum Adat used it as the entry point in revitalizing the Minangkabau tradition.

The Pemdas (local governments) in West Sumatera, as the representation of the Indonesian government, the $A B S S B K$ is not only a cultural construction, but also political. They made that the cultural jargon as the main orientation of their policies which are embeded in the new local laws and regulations. Thus, the $A B S S B K$ becomes legally formal aspect of life. The moral concerns, religious values, and the discourse of improving the faith and piety to Allah SWT (God) have become the basic considerations for the government in setting up this political "project" since 2000.

In general, the $A B S S B K$ socio-political project was started by an agitation against the growing occurrences of infidelity within the society such as gambling, drugs, and others as included in the introduction to the Padang City Major policy known as Instruksi Walikota Padang Nomor 451.465/Binsos-III/2005.[12] This condition is considered as paradox in a society which highly bond them self with the philosophy of $A B S S B K$.It was emphasized by the quote of Qur'anic verses in the major's circular letter known as Surat EdaranWalikota PadangNomor 451.1397/ Binsos-VIII/2005 [13] which explain that every those who have faith on Allah SWT and the after life will consistently do shalat (pray), pay their zakat (alms), and fear not others but Allah SWT will be granted by His guidance (QS. At Taubah: 18). And, one which explains that shalat prevents one from doing vicious acts (QS. Al Ankabut: 45).

Those political acts started the National "religious revolution". The Perda on anti-adultery by the government of West Sumatera province initiated the simultaneous born to Perda by the regencies and cities government in West Sumatera. Those Perdas include Perda No. 9/2000 in Bukittinggi City, Perda No. 1/2001, and No. 2/2002 in Solok Regency, Perda No. 2/2003 and Perda No. 21/2003 in Pasaman Regency, Perda No. 5/2003 and No. 6/2003 in 50 Kota Regency, No. 1/2003 and Perda No. 2/2003 in Sawahlunto-Sijunjung Regency, Perda No. 6/2003 in Padang City, Perda No. 8/2004, and No. 4/2004 in Pesisir Selatan Regency, Perda No. 02/2004 in Padang PariamanRegency, Perda No. 6/2005 and No. 6/2005 in Agam Regency, Perda No. 4/2005 and No. 4/2006 in Pesisir Selatan Regency, and Perda No. 7 Tahun 2007 in West Sumatera Province. Moreover, there are also the Regent Circular Letter Tanah Datar Regency No. 451.4/556/Kesra-2001 and No. 460/311/Kesra-2002, The Coordinated Warning Letter between 50 Kota Regent and Payakumbuh City Major on 5th February 2005, Padang City Major Instruction No. 451.422/ Binsos III/2005, and the Circular Letter of Solok Regent No. 400/121/Kesra-2006.

Those Perdas and instructions or letters of the head local government bond obligated the students from elementary to senior high schools including University students, government employees, TNI (Indonesian ARMY), POLRI (Indonesian Police) to wear muslim dress and able to read and write the Qur'anic letters. The letter of Padangpanjang City Major No. $800 / 244 / B K D-P P / 2003$ provide even detail regulation on the dress.

The "religious revolution" was inspired by the increasing concerns of common moral degradation, therefore the government would be ignorant if it took role and action on implementing the philosophy of $A B S S B K$ such as covering your aurat (genitals) and others which represent the Islamic way of life in order to achieve a prosper society. The government with the Perda, by this, put aside the West Sumatera citizen of other religions. It is undeniable facts that the governments in the West Sumatera between 2000 and 2007 were trying to construct an image of "green area" for Muslims, although they were aware that people of other religions live as the citizen of West Sumatera. One of the most enthusiast local governments was the Padang city major, Fauzi Bahar. 
Padang is not only the capital of West Sumatera Province, but it is also the gate for others to know about the society of West Sumatera. The dynamics in Padang is a portrayed the reality of Minangkabau society as a whole. Besides, Padang was also considered as example for other local regencies and cities in implementing ABSSBK's inspired Perdas and policies.

The rapid change of Padang into "kota santri" (muslim friendly city) started to be seen after the inauguration of Fauzi Bahar as the city major in 2003. The early year of Fauzi Bahar's leadership was prioritized on annihilating the togel (gambling) and alcoholic issues. The success in overcoming the issues created a momentum at the elites to raise the issues on muslims' dress, Qur'an literacy and the Islamic teaching[14]. The making of Ranperda (local regulation plan) initiated by DPRD Sumbar (House of Representative in West Sumatera) in 1999-2004 was based on the Minangkabau philosophy known as ABSSBK [15]. The ABSSBK was claimed to have degraded within the practices everyday life, particularly in the fashion style which no longer represent the philosophy of $A B S S B K$. One of the case was the vulgar stage dress of Dangdut singer named Inul Daratista. Thus, Padang published a Perda No. 6 tahun 2003 which obligates the public and Islamic elementary school (SD \& MI) to be able to read the Qur'an [16].

The government "religious revolution", although seemed to run smoothly, earned criticisms [27]. However, the criticisms did not affect the role and function of ulama within the government. Those contras addressed more at the inaccuracy of its implementations. The case can be seen in the asmaulhusna (99 names of God) memorizing competition, and implementation of hijab (women to cover their hair) as mandatory school dress for female students which promoted by DPRD [17]-[19], ulama, and Kaum Adat [20]. The other social exponents such as universities, media and scholars who pose the ability to contest this government religious trend seemed to accept this "religious revolution" ala the government of West Sumatera.

Kaum Adat seemed to see these Islamic interventions within the government of West Sumatera would be a kind of contestation with the ulama under the discourse of $A B S S B K$. They, however, also realized that ulama carried the interest of Islamization in the ABSSBK discourse which can be seen through radicalist movements againts the issue on Ahmadiyah, al Qiyadah, and restourant sweepings during Ramadhan month. There were also boycotts against the events which were accused to be anti-ABSSBK [21]-[24].

Kaum Adat, after considering those factors, made more strategic efforts by promoting the ideas of revitalizing the Minangkabau traditions through culture and education. Avoiding the pros-and-cons against the implementation of perdas which implied the initiation of Syari'i Country and religious radicalism, they strategically infiltrated the ideas of revitalization of tradition into the text books used in Elementary Schools, Junior and Senior High Schools which directly yet silently put those ideas in the school curriculums. The books were published by in the context of BAM (Minangkabau Culture) which taught only the Minangkabau traditions, and excluding the Islamic issues. Besides, the elites of Kaum Adat, managed to convince the Government to implement the concept of "Kembali ke Nagari" (return to the Nagari system) by establishing Nagari Adat (Traditional / Cultural Villages).

The establishments of Nagari Adat by Kaum Adat, for example, was done at Nagari Situjuah Batua in 50 Kota Regency. Although they name it as Nagari Adat, they used the Islamic values as promoted by ABSSBK. The opening ceremony of the Nagari Adat was attended by Vice Regent of 50 Kota Regency, Irfendi Arbi.

Nagari Adat implement the Perna (Nagari regulation) which consist of old tradition, which claimed to have adopted the Islamic life style. Every children of Situjuah Batua, for example, are obligated to cover their aurat in public places, practice shalat regularly and read Qur'an 
every night. A Dubalang was assigned to watch over the conducts of this Perna. Those who violate the Perna will be fined or excluded from the society. Besides, the societies were also prohibited to play koa, remi (card games), domino and were obligated to attend the wirid (religious course) in the mosque from Thursday to Friday evening. All warung (local shops) should all be closed during the wirid. Out of those regulations, the society are allowed to conduct their life as usual [25].

The establishment of Nagari Adat by Kaum Adat started to spread such as at Taram, Andaleh, Sungai Beringin, and VII Koto Talago, in 50 Kota Regency[26]. Moreover, Kaum Adat also agreed to make a Holly Day called Absyar (Adat Basandi Syarak, Syarak Basandi Kitabullah/ ABSSBK) Day every Thursday 18:00 to Friday 18:00 wib. One of the activities in Absyar Day is to stop playing domino, koa, remi and other games which resemble gambling.

\section{CONCLUSIONS}

In 1999 was the turning point for the West Sumatera society, culturally and structurally, which is marked by the implementation of "Kembali ke Nagari" (Return to Traditional Village System) and"Kembali ke Surau" (Return to Islamic Life Style) discourse. There were three important exponents which acted as the initiator; KaumAdat, Kaum Agama, and Government which is represented by Pemda (Local Government). These three components made substanstial contributions in redefining Minangkabau identity. The question of whom and what is called as the Minangkabau was constructed differently and negotiated among the three. The three seemed to agree that identity construction was placed within the project of $A B S S B K$.

In the early stage of the "project", those three were very enthusiastic with the concept of "Kembali ke Nagari" and "Kembali ke Surau" under the ABSSBK project. However, those three took a stand on their own ground if not taking over each other's role and fuction in the socio-political structure. It can be seen that Kaum Agama tends to cover the issues of heresy, and those which disturbed the stability of socio-political situation of the muslim citizen. Meanwhile, the government took care of religious-mass ceremonial events. Only Kaum Adat that took strategically role by imposing the necessity of Minangkabau culture revitalization, in which they made propaganda to set "conflict" between the discourse of original identity and western culture identity among the young generation of the Minangkabau.

\section{REFERENCES}

[1] M. Budiman, "The middle class and morality politics in the envisioning of the nation in post-Suharto Indonesia," Inter-Asia Cult. Stud., 2011.

[2] S. E. Wieringa, "The birth of the new order state in Indonesia: Sexual politics and nationalism," J. Womens. Hist., 2003.

[3] N. Hasan, "Reformasi, Religious Diversity, and Islamic Radicalism after Suharto," J. Indones. Soc. Sci. Humanit., 2008.

[4] E. Morell, "Strengthening the Local National Reform: A Cultural Approach to Political Change," J. Southeast Asian Stud., vol. October, 2001.

[5] J. Linnekin, "Cultural Invention and the Dilemma of Authenticity," Am. Anthropol., 1991.

[6] T. Abdullah, "Adat and Islam: An Examination of Conflict in Minangkabau," Indonesia, vol. 2, no. October, 1966.

[7] T. Abdullah, "Adat, Nasionalisme, dan Strategi Kultural Baru," Genta Budaya, vol. 3, 
Tahun 1, no. Februari-April, 1996.

[8] A. Azra, Pendidikan Islam: Tradisi dan Modernisasi Menuju Milenium Baru. Jakarta: P.T Logos.

[9] C. Dobbin, Gejolak Ekonomi, Kebangkitan Islam, dan Gerakan Paderi Minangkabau 1784-1847. Jakarta: Komunitas Bambu, 2008.

[10] T. Abdullah, School and Politic: The Kaum Muda Movement in West Sumatra. NY: Cornell University, 1971.

[11] J. Hadler, "A historiography of violence and the secular state in Indonesia: Tuanku Imam Bondjol and the uses of history," Journal of Asian Studies. 2008.

[12] Pemda, "Pengantar Instruksi Walikota Padang Nomor 451.465/Binsos-III/2005." Kantor Walikota, Padang, 2005.

[13] Pemda, "Surat Edaran Walikota Padang, Nomor 451.1397/ Binsos-VIII/2005." Kantor Walikota, Padang, 2005.

[14] P. Ekspres, "No Title," 01-Jul-2004.

[15] Haluan, "No Title," 27-Jul-2004.

[16] Singgalang, "No Title," 25-Jun-2005.

[17] P. Ekspres, "No Title," 23-Apr-2008.

[18] P. Ekspres, "No Title," 26-Apr-2008.

[19] P. Ekspres, "No Title," 28-Apr-2008.

[20] P. Ekspres, "No Title," 15-Mar-2009.

[21] P. Ekspres, "No Title," 30-Oct-2007.

[22] P. Ekspres, "No Title," 31-Oct-2007.

[23] P. Ekspres, "No Title," 19-Jan-2008.

[24] P. Ekspres, "No Title," 15-Feb-2009.

[25] P. Ekspres, "No Title," 06-Oct-2008.

[26] P. Ekspres, "No Title," 19-Feb-2009.

[27] K. Saddhono, "Integrating Culture in Indonesian Language Learning for Foreign Speakers at Indonesian Universities." J. of Lang. and Lit. vol. 6 no.2 pp. 349-353, 2015 